\title{
TRAGIC THOUGHT: ROMANTIC NATIONALISM IN THE GERMAN TRADITION
}

\author{
Patricia AnNe Simpson*
}

Thus I came among the Germans ... It is a severe word, but I will say it, because it is true. I can think of no people more torn than the Germans. You see craftsmen, but no human beings, thinkers, but no human beings, priests, but no human beings, masters and slaves, youths and elders, but no human beings-is it not like a battle field where hands and arms and all severed limbs lie about while the life blood flows into the sand?

—from Hölderlin's Hyperion

And all this at a time when the German mind, which, not so very long ago, had shown itself capable of European leadership, was definitely ready to relinquish any aspirations of this sort and to effect the transition to mediocrity, democracy, and "modern ideas"-in the pompous guise, to be sure, of empire building. The intervening years have certainly taught me one thing if they have taught me nothing else: to adopt a hopeless and merciless view toward that 'German temper', ditto toward German music, which I now recognize for what it really is: a thoroughgoing romanticism, the least Greek of all art forms and, over and above that, a drug of the worst sort, especially dangerous to a nation given to hard drinking and one that vaunts intellectual ferment for its power both to intoxicate the mind and to befog.

$$
\text { -from Nietzsche's Birth of Tragedy }
$$

Why, in the context of an epistolary novel from the late 18th century, does Hölderlin inscribe his tirade against the Germans? Or, more specifically, why does he set up the opposition between Greeks and Germans? Why are the Greeks the 'opposite' of the Germans? The novel, Hyperion, in conjunction with the 'Vaterländlische Hymne', set up the opposition between Greek and German art that Hölderlin tries to reconcile. Hegel contemplates the relationship between aesthetic education and the responsibility of the 'citizen' in the state. Later, at perhaps the culmination of romantic thought, Nietzsche, in the ruminations about tragedy, feels compelled to excoriate German music and statehood together. To answer the questions that relate the aesthetics of romanticism to the roots of German nationalism, one must take into account a tradition of philosophical speculation about the relationship between the self and the other, if it is indeed a relationship at all, and the totalising power of the dialectic that gained full force during the period we refer to as German romanticism.

The reception of romanticism for nationalistic purposes has become notorious since World War II, when the Nazis exploited the obsession with German roots. The later condemnation of romanticism in the G.D.R. for its rampant

*Germanic Languages and Literatures/3110 MLB, University of Michigan, Ann Arbor, MI 48209-2375, U.S.A. 
subjectivity and for its focus on the dark side of the mind has compounded the problem of addressing the relationship between romantic aesthetics and politics. Again, we face the familiar fear, justified or not, of resurgent German nationalism within the context of a united Germany. Do the roots of nationalism lie in romanticism? Or is their proximity a cliché perpetuated by the chauvanistic misreading of Hölderlin, Nietzsche, Wagner. Is it the collusion between art and state exploited epically in Hans-Jürgen Syberberg's film 'Our Hitler', where the figure of Adolf Hitler rises from a classical grave, wrapped in a toga, accompanied by pulsating strains of Richard Wagner?

The relationship between art and the state seems to be at the root of the answers to the above questions. In Hegel's Phänomenologie des Geistes (Phenomenology of Spirit) and the Vorlesungen über die Ästhetik (Lectures on the Aesthetics), the role of the dramatic stage in a democracy and its pedagogical power is foregrounded in a discussion of tragedy. I would argue that his concept of the state is derived from a totality informed by the aesthetics of Greek drama. There is an interdependent relationship between his aesthetic and political theory. The reference to Hölderlin's Hyperion (and the later Hymne) supports this claim. Hölderlin, in the persona of a disidealised Greek youth, moves through an aesthetic and ethical education. Finally, upon coming to Germany, described as a battlefield, Hyperion criticises in the most violent possible terms the inhumanity of the German people. The relationship of aesthetics to politics and the development of a national literature to nationalism anticipates and determines Nietzsche's later claims in the Geburt der Tragödie (Birth of Tragedy), as well as in the essay Vom Nutzen und Nachteil der Historie (On the Utility and Disadvantage of History).

These works have in common the central problem of the relationship between the self and the other. The dialectical force of the definition of the German as the non-Greek, and the attempt to recuperate this definition of self in an elevated art, indicate the force of the dialectic which relies on identity and difference. It is ultimately the totalising power of dialectical thought that connects romanticism and nationalism in German literature, philosophy, and history. For the drive toward organic whole and the compulsion to eliminate difference hinges on the belief that the 'other' must be recuperated or eliminated from the system of scientific thought. This dialectic carries along with it questions of history, of forgetting, of belatedness, and finally, of irony and its counterpoint, pathos.

The stage plays an important role in German intellectual and political history. As early as the mid-18th century, Lessing called for a national theatre to unify German culture in the absence of political unity. We are too familiar perhaps with Schiller's proposal: to use the stage as a medium for an aesthetic education. In this century, Brecht and his theory of epic theater clinch the political purpose of the theater: to send people to the barricades. Ironically, Brecht became an instrument of control and censorship in the G.D.R., where the alternative illegal theater groups who tried to reclaim the revolutionary Brecht as part of their own 'cultural inheritance' were relentlessly pursued and harassed by the Stasi. One need only think of the pre-revolutionary status of Vaclav Havel, the playwright, later president, who knows the political potential, and the potentially incendiary capacity, of the stage. The stage has the power to set example, but also to set a negative example. It has the power to effect the performative capacity of 
language; it convinces, it instructs, it persuades. For this reason, the state has a vested interest in exerting control over the stage, either in overt instances of censorship or, more subtly, in instances of withheld subsidies.

In Hegel, the relationship between aesthetics and ethics focuses on the role of the subject: the subject in art is the same, he would assert, as the subject in the state. Within the Phenomenology, a kind of Bildungsroman for absolute spirit, Hegel posits a relationship between the individual and the state that informs the later Aesthetics. In the midst of a description of the ethical realm which constitutes a self-divided whole, Hegel writes of the role of consciousness and consciousnessless, ascribing the former to men and the latter to women.

The one extreme, the generally conscious spirit, is joined together with its other extreme, with the consciousless spirit, with its power and its element, through the individuality of the man. On the other hand the divine law has its individualization or the consciousless spirit of the individual has its existence in the woman, from the unknowing and the unknown in reality steps out into the conscious realm. The unity of man and woman constitutes the active middle of the whole and the element, which, divided into the extremes of the divine and human law, and is its unmediated unity, which joins both of the first conclusions with the opposite movement (:) of reality to unreality above--of human law, which organizes itself into independent limbs, below to danger and preservation of death-and of the subterranean law up to the reality of the day and to conscious existence, which is unites the realm of the man, with that of woman. ${ }^{1}$

The role of the consciousless spirit is assigned to the Weib, to the woman in Hegel's dialectic, and it is also the realm of divine, subterranean law. This stage, or state is described in terms of negation. The conflation here of logical with legal terms signals the collapse of the intended opposition between the realm of reality and of rhetoric. The cause or source of this collapse is the source of the argument itself, namely Antigone. The place of the immediate union of the principles of human and divine, community and individual, conscious and unconscious, day and night, male and female, pathos and irony, must be within a philosophy of art, or an aesthetic. At this moment, Hegel inscribes ethical behavior into the aesthetic moment. The extremes or poles figured by Mann and Weib are characterised by their relationship to consciousness. The female principle carries unconsciouslessly the internalisation of divine law and functions as its mediation within the community. Hegel assigns to the female the domain of underground law, the laws of the dead and of darkness; to the male, he assigns the role of consciousness and light. The obvious oppositions of darkness and light with unconscious and conscious are sublated in the Vereinigung. The impossibility of this union is the topic of tragedy. Here we have a moment of Hegel's dialectic in which identity and difference are defined by opposition. We move at this moment to the Aesthetics, in which Hegel posits the sacrificial model of tragedy.

In the third part of his Vorlesungen über die Ästhetik, Hegel writes not only a philosophy of art, but also a skewed version of history. Hegel sustains the aesthetic as a critical category, indicated by the division into the Classical, the Romantic, and the Symbolic. Hegel's concern with ethical behavior informs his aesthetics. The theory of tragedy derives almost exclusively from Greek examples, and the resulting theory is based on a nostalgia 
for the lost object, for the Greek world that is no more. The Greeks, the originators of dramatic poetry, set the standard:

Denn nur in den heroischen Tagen können die allgemeinen sittlichen Mächte, indem sie weder als Gesetze des Staats noch als moralische Gebote und Pflichten für sich fixiert sind, in ursprünglicher Frische als die Götter auftreten, welche sich entweder in ihrer eigenen Tätigkeit entgegenstellen oder als der lebendige Inhalt den freien menschlichen Individualität selber erscheinen. ${ }^{2}$

(For only in the heroic days could the general ethical powers, in that they are fixed neither as laws of the state nor as moral commandments and duties, appear as the gods in original freshness, gods who either are opposed to each other in their own activity or appear as the living content of the free human individuality itself.)

Hegel posits individual freedom as a prerequisite for tragedy with all the political resonance of that word:

Denn zum wahrhaft tragischen Handeln ist es notwendig, daß das Prinzip der individuellen Freiheit und Selbständigkeit oder wenigstens die Selbstbestimmung, für die eigene Tat und deren Folgen frei aus sich selbst einstehen zu wollen, erwacht sei (534).

(Then for truly tragic action, it is necessary that the principle of individual freedom and independence be awakened, or at least self-determination to be willing to take responsibility freely for one's own actions and their consequences.)

Implicit in the theory of tragedy is a theory of the state. Democracy is then a prerequisite for true tragedy.

At this juncture, I will turn to Nietzsche and his theory of tragedy both in the Birth of Tragedy and the essay on the Utility and Disadvantage of History. Nietzsche equates democracy with mediocrity, and 'modern ideas', as indicated in the excerpt from the Birth of Tragedy that stands as an epigraph for this paper. The essay posits a theory of necessary forgetting, of specifically German forgetting of its own belatedness. What one has to forget is that one has appropriated that which is 'other' and 'foreign' and made it one's own:

...ich meine jene Kraft, aus sich heraus eigenartig zu wachsen, Vergangenes und Fremdes umzubilden und einzuverleiben, Wunden auszuheilen, Verlorenes zu ersetzen, zerbrochene Formen aus sich nachzuformen. ${ }^{3}$

(...I mean that ability to grow from one's own, to reshape that which is past and foreign and to incorporate it, to heal wounds, to replace that which is lost, to reform broken forms.)

Nietzsche here describes the dialectical appropriation of the 'other' into the self. As the argument develops, he insists on the equal importance of the 'unhistorical' (117) for the 'health' of a people and its culture. He goes on to critique the 'modern' German for his weakness of personality and the contradiction between form and content: 
Die Form gilt uns Deutschen gemeinhin als eine Konvention, als Verkleidung und Verstellung und wird deshalb, wenn nicht gehaßt, so doch jedenfalls nicht geliebt; noch richtiger würde es sein, zu sagen, daß wir eine außerordentliche Angst vor dem Worte Konvention und auch wohl vor der Sache Konvention haben (133).

(For us Germans, form is convention, a masking and distorting, and for that reason it is if not exactly hated, then not exactly loved; still it would be more correct to say that we have an extraordinary fear of the word convention and also for the thing itself.)

Nietzsche uses this fear of convention to define German architecture. He cites the example of a German city which, when compared to the national style of foreign cities (134), seems to define itself in negatives: colorless, used up, badly copied, slovenly (134). The German city lacks its own specificity. It negates, rather than defines itself. From this Nietzsche moves to the German strength: Innerlichkeit, or interiority, which renders the Germans 'actors'. In the face of this problem, Nietzsche conflates the personal division with the political in a moment of specular unification:

... so soll ich hier ausdrücklich mein Zeugnis stehen, daß es die deutsche Einheit in jenem höchsten Sinne ist, die wir erstreben und heißer erstreben als die politische Wiedervereinigung, die Einheit des deutschen Geistes und Lebens nach der Vernichtung des Gegensatzes von Form und Inhalt, von Innerlichkeit und Konvention (136).

(... so here I should expressly confess, that German unity in highest sense, which we strive for and strive for more hotly than political reunification, is the unity of the German spirit and life after the destruction of the opposition of form and content, of interiority and convention.)

In this moment, Nietzsche privileges spiritual over political unity, but he arrives at this philosophical position through aesthetic deliberation, through the problem of form and content, of content and its expression. He imposes an aesthetic model on the state, and in so doing, moves from tragedy to irony:

...der Glaube, Spätling und Epigone zu sein ... durch dieses Übermaß gerät eine Zeit in die gefährliche Stimmung der Ironie über sich selbst und aus ihr in die noch gefährlichere des Zynismus: in dieser aber reift sie immer mehr einer klugen egoistischen Praxis entgegen, durch welche die Lebenskräfte gelähmt und zuletzt zerstört werden (136).

(...the belief in being latecomers and epigones...through this excess an era falls into a dangerous mood of self-irony and from that into a more dangerous one of cynicism: in this, however, the era matures against an intelligent egotistical practice through which the lifes forces are crippled and finally destroyed.)

The consciousness of history cripples, according to Nietzsche. He blames Hegelian philosophy for the 'crippling education' (156), the heavy weight of historical knowledge. The debilitating ironic consciousness bequeathed by historical knowledge is the source of danger, Nietzsche asserts. It is like 'living in the 5th act of a tragedy' (154). He instead calls for a shift in thinking of history 
from memento mori to memento vivere. The problem with politics is poetry:

...und doch fällt dieser Glaube dahin, wie der platonische Staat dahin gefallen wäre, wenn einmal der Notlüge eine Notwahrheit entgegengestellt wird: daß der Deutsche keine Kultur hat, weil er sie auf Grund seiner Beziehung gar nicht haben kann. Er will die Blume ohne Wurzel und Stengel: er will sie also vergebens. Das ist die einfache Wahrheit eine unangenehme und gröbliche, eine rechte Notwahrheit (170).

(... and still this belief falls the way the Platonic state would have fallen, if once the necessary lie had been opposed by a necessary truth: that the German has no culture, because, on the basis of his relation, he can have culture. He wants the blossom without the roots and stem: he thus wants it in vain. That is the simple truth, an unpleasant and a crude, a correct necessary truth.)

The fault of the German people is the problem of German culture: it does not exist, cannot exist, because it is derivative and belated. Nietzsche suggests forgetting, repressing history, in order to overcome the problem. It is a history we can not afford to forget.

University of Michigan

Patricia Anne Simpson

\section{NOTES}

1. G.W.F. Hegel, Phänomenologie des Geistes (Frankfurt a/M: suhrkamp taschenbuch wissenschaft, 1973), pp.341-342. I offer my own, literal translation to preserve the syntax of Hegel's original. Further citations from this text will be indicated by page numbers in parentheses.

2. G.W.F. Hegel, Vorlesungen über die Ästhetik (Frankfurt a/M: suhrkamp taschenbuch wissenschaft, 1986), III, p. 539.

3. Friedrich Nietzsche, 'Vom Nutzen und Nachteil der Historie', Werke in zwei Bänden (Munich: Carl Hanser Verlag, 1967), I, 116. All direct quotations are taken from this text. Page numbers are indicated in parentheses. 